American Journal of Environmental Sciences 5 (6): 698-705, 2009

ISSN 1553-345X

(C) 2009 Science Publications

\title{
Comparison of Daily and Monthly Results of Three Evapotranspiration Models in Tropical Zone: A Case Study
}

\author{
${ }^{1}$ Seyed Reza Saghravani, ${ }^{1}$ Sa' ari Mustapha, ${ }^{2}$ Shaharin Ibrahim and ${ }^{3}$ Elias Randjbaran \\ ${ }^{1}$ Department of Chemical and Environmental Engineering, Faculty of Engineering, \\ University Putra Malaysia, 43400 Serdang, Selangor, Malaysia \\ ${ }^{2}$ Department of Environmental Science, Faculty of Environmental Studies, \\ University Putra Malaysia, 43400 Serdang, Selangor, Malaysia \\ ${ }^{3}$ Department of Mechanical and Manufacturing Engineering, Faculty of Engineering, \\ University Putra Malaysia, 43400 Serdang, Selangor, Malaysia
}

\begin{abstract}
Problem statement: Evapotranspiration (ET) has crucial role in agricultural activity, water management and hydraulic engineering. Recently many forms of the equation have been applied for estimating daily and monthly evapotranspiration around the world. Approach: In this study, the daily and monthly ET was estimated by Penman, Penman-Monteith (P\&M) and Hargreaves equation to evaluate general relationships for estimating monthly and daily values of these 3 methods and also effect of different parameters such as Humidity and wind speed on fluctuation of ET. Results: The results showed that maximum and minimum values were belonging to Hargreaves and P\&M models, respectively. Conclusion: Statistical analysis showed significant difference among the three methods and coefficient variant for daily and monthly analysis was 18.49 and 7.17 respectively. However, the difference between mean value of P\&M and Hargreaves, that has the most different, is $1 \mathrm{~mm}^{\text {year }}{ }^{-1}$.
\end{abstract}

Key words: Penman, Penman-Monteith, hargreaves, equation, Serdang, Malaysia

\section{INTRODUCTION}

Evapotranspiration (ET), is one of the major components of the hydrologic cycle $^{[28]}$, combines evaporation (E) from soil and plant surfaces and transpiration (T) from plants ${ }^{[17]}$. ET describes the loss of water from crop and soil to the air over a long period to elucidate its relationship with annual precipitation ${ }^{[16]}$. This process is very significant in many scientific fields such as irrigation scheduling ${ }^{[1]}$.

Estimation of ET is an important path to study of hydrology, climate, agricultural, water balance, planning, design and operation of irrigation systems, crop-growth models ${ }^{[2,14,17,23,28]}$ and as efficient parameter in surface and subsurface modeling processes for MODFLOW, MIKESHE and HEC-HMS.

In addition financial and economic research, industrial engineering research, meteorology and agroecological research studies has been approached to $\mathrm{ET}^{[17]}$ and imprecise estimation of ET can lead to poor investigation of water and efficient management of water in future for reliable application ${ }^{[14]}$.
Direct measurements of ET around the world are rarely available and apply to provide an opportunity to improve the quality of ET which has collected by different hydrologic model ${ }^{[25]}$ because direct measurement of ET implement by high-cost micrometeorological techniques based on energy balance and water vapor mass flux transfer methodologies ${ }^{[17]}$.

Before 1938, Veihmeyer from University of California had represented data and information on crop evapotranspiration, using gravimetric method ${ }^{[9]}$. For the past 50 years, almost 700 registered empirical methods for different weather had been employed by scientist to determine $\mathrm{ET}^{[1]}$. These methods widely express the amount of ET by a mathematical formula based on their understanding of component process ${ }^{[6]}$. Some of these methods include Penman, Jensen-Haise, Turc, Food and Agriculture Organization (FAO) Penman-Monteith, Makkink, Penman-Monteith (P\&M), Priestley-Taylor, FAO Blaney-Criddle, Hargreaves-Samani and Thornthwaite can estimate ET at varying locations and climatic conditions ${ }^{[2]}$.

Corresponding Author: Seyed Reza Saghravani, Department of Chemical and Environmental Engineering, Faculty of Engineering, University Putra Malaysia, 43400 Serdang, Selangor, Malaysia 
Equations are applied to calculate the ET range in sophistication from solar radiation equations temperature based on equations or the complex combination of both of them ${ }^{[12]}$. Different factors which always affect ET are (1) weather parameters, (2) crop factors and (3) management and environmental conditions $^{[1]}$. Due to the mutual dependence of these factors and variability in different part of earth surface, it is difficult to introduce an equation that can calculate ET under different weather parameters ${ }^{[17]}$. Another difficulty in calculation of ET is the lack of accurate and precise row information from various sites in study area. Most of the sites do not have continuously measured climate data for basic weather parameters. However, the parameters that are measured in stations have the systematic and/or random errors in solar radiation, relative humidity, air temperature and/or wind speed. The uncertainty in these parameters can lead to significant errors in the estimated $\mathrm{ET}^{[8]}$.

Computation of ET often applied models which have been different simplifying assumptions, input requirements and system boundaries. For instance, it mentioned above, various models of the water-plantatmosphere system existed. This requires large input parameter and needs site-specific calibration or validation $^{[14]}$.

In 1956 Penman-Monteith (P\&M) represented one equation, which combined energy and aerodynamic considerations and requires measurement of net radiation, soil heat flux, air temperature, relative humidity, wind speed and other environment-specific variables for calculating $\mathrm{ET}^{[25,26]}$. This equation removed weaknesses of Penman combination equation in computation of the wind function, vapor pressure deficit and net long wave radiation. Accuracy and reliability of P\&M method has been studied by scientists and researchers numerously ${ }^{[13,19]}$. It has been mentioned in literature that different between soil evaporation and plant transpiration and treats the land surface as one homogeneous layer cannot be distinguished by P\&M equation. Due to the fact that this model has been used in many evapotranspiration calculation studies as a reliable method for calibration and comparison between other methods under different climate conditions ${ }^{[1-3,5,12,13,20,22,29]}$.

There are a lot of investigations about estimating ET by various methods such as by Jensen et al.$^{[13]}$. They assessed 19 different methods in 11 various climatologic conditions. In comparison with their lysimetric evaluation, $\mathrm{P} \& \mathrm{M}$ was ranked as best method to yield estimates close to daily and monthly observed ET values. This methods has two advantages in comparison with other methods, (1) well documented method in comparison to using lysimeters under a wide range of climate conditions, (2) it can yield good results under a variety of climate scenarios ${ }^{[5]}$. In the absence of lysimetric data Penman-Monteith equation is appropriate for finding error of another methods ${ }^{[17]}$.

Many researchers have recommended the standardization of the P\&M equation for estimation of $\mathrm{ET}^{[1,12]}$. Later, $\mathrm{FAO}$ has proposed the FAO-P\&M equation with small changes for standardization of this $\operatorname{method}^{[4]}$. It needs air temperature, relative humidity, wind speed and solar radiation to compute the $\mathrm{ET}^{[4,5,11]}$. The lack of one, or more, climate variable physically related to evaporation and transpiration processes inescapably reduces the accuracy of evapotranspiration estimation $^{[4]}$.

Allen et $a l .{ }^{[1]}$ have demonstrated this particular reduced set of $\mathrm{P} \& \mathrm{M}$ method, when used with data from well watered sites to produce ET values that are not significantly different from those forms which structure the FAO-P\&M for multi day periods.

The empirical Hargreaves equation, as temperature based method which requires only maximum and minimum air temperature, has shown good results in different type of climate ${ }^{[1,12,13,27]}$. It should be noted that the maximum and minimum air temperatures are usually available at weather stations round the world ${ }^{[5]}$ and it can be increased the usage of Hargreaves equation enormously.

Gavilán et al. ${ }^{[7]}$ mentioned that Hargreaves equation is sensitive to sensible heat advection and under severe advective conditions it can underestimate daily ET0 by about $25 \%$. Some scientists declared that the method should be adjusted to local condition with propose of improving the estimation.

It is obvious that temperature range in Hargreaves et $a l .{ }^{[11]}$ equation accounts for effects of cloudiness and that temperature range generally decrease with increasing cloudiness. Also temperature range relates with humidity and vapor pressure deficit and is inversely influenced by wind speed ${ }^{[9]}$.

Jensen et al.$^{[13]}$ compared 20 reference ET methods against lysimeter measurements at 11 stations around the world. According to them, Hargreaves method ranked best of all methods that required only air temperature data.

Various studies have compared Hargreaves equation against directly measured ET or against ET predicted by some other ET methods. Hargreaves et al. ${ }^{[1]}$ and Temesgen et al. ${ }^{[27]}$ compared ET values from the FAOP\&M with Hargreaves for paired weather stations and found small different in comparing the two methods. The equation self compensates for the lack of resistance and humidity data required by the Penman and PenmanMonteith methods. 
In comparing between Hargreaves and FAO-P\&M equation based on the World Water and Climate Atlas of the International Water Management Institute (IWMI) for more than 3,000 weather stations worldwide, Hargreaves predicts the ET similar or maximum 1 $\mathrm{mm} /$ day to FAO-P\&M method in most tropical locations of the globe with the exception of desert regions. Therefore the temperature range is significant in equatorial zones and there are no substantial problems associated with applying Hargreaves equation at low latitudes and found good agreement between the two methods over a wide range of climates daily and monthly ${ }^{[9,10]}$.

The basic goal of the study is to examine whether possibility of achieving reliable information of two ET estimation methods, Hargreaves-Samani and FAO$\mathrm{P} \& \mathrm{M}$, as compared to the PM method for the grass reference using data collected in Serdang, Malaysia in latitude only about $3^{\circ}$. The P\&M method was chosen as a benchmark for comparison in this study because there were no measured ET data in the study area. The objective for such comparisons is to find the significant difference between methods as compared to the PM equation.

\section{MATERIALS AND METHODS}

Description of study site: The 700 ha tropical study area, Latitude $2^{\circ} 59^{\prime}-3^{\circ} 00^{\prime} \mathrm{N}$, Longitude $101^{\circ} 42^{\prime}$ $101^{\circ} 43^{\prime} \mathrm{E}$, is located in the South of Kuala Lumpur, Malaysia (Fig. 1). The location is characterized by clay loam, sandy clay and sandy silt soil as Kajang Formation. The groundwater table was estimated to be $30-85 \mathrm{~cm}$ below ground surface and the range of landsurface altitudes at the study site varies between 36 and $40 \mathrm{~m}$ above mean sea level.

Two years (from November 1, 2006 until October $31,2008)$ daily meteorological data was obtained from the University Putra Malaysia weather station. According to Linsley et $a l^{[18]}$ every weather stations is enough to cover $25 \mathrm{~km}^{2}$. Hence according to this requirement 1 station would be enough for present study area. The weather station selected was equipped with electronic sensors to monitor the air temperature, relative humidity, precipitation, wind speed, solar radiation, soil moisture, soil temperature at 5, 10 and $20 \mathrm{~cm}$ depths and barometric pressure. The average annual maximum and minimum daily air temperatures are 33.01 and $23.18^{\circ} \mathrm{C}$, respectively. The average annual wind speed at $2 \mathrm{~m}$ height is $0.76\left(\mathrm{~m} \mathrm{sec}^{-1}\right)$. Average annual air humidity is $94 \%$. The average annual rainfall of the area is about $2996.3 \mathrm{~mm}$. The groundwater level is varying in study area from ground surface between 1 and $10 \mathrm{~m}$. The entire region is covered by vegetation consisting mainly of trees, shrubs, grass and low bush.

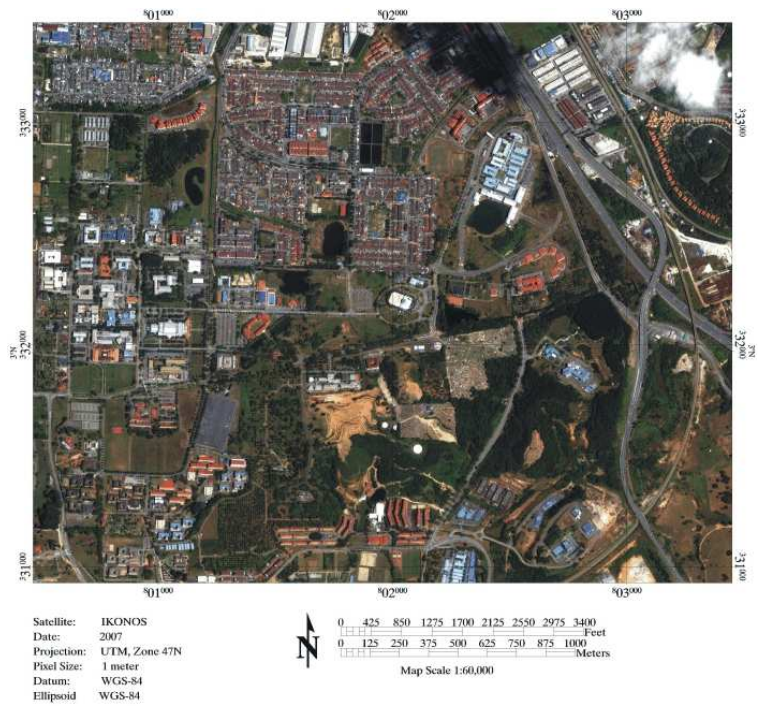

Fig. 1: General view of study area

\section{Evapotranspiration model:}

Penman-Monteith equation ${ }^{[21]}$ : The model can be expressed as:

$$
\mathrm{E}_{\mathrm{T}}=\frac{\Delta \mathrm{R}_{\mathrm{n}}+\left(\mathrm{e}_{\mathrm{a}}-\mathrm{e}_{\mathrm{d}}\right) * \frac{\rho * \mathrm{c}_{\mathrm{p}}}{\mathrm{r}_{\mathrm{a}}}}{\lambda\left(\Delta+\gamma *\left(1+\frac{\mathrm{r}_{\mathrm{s}}}{\mathrm{r}_{\mathrm{a}}}\right)\right)}
$$

Where:

$$
\begin{array}{lll}
\mathrm{R}_{\mathrm{n}} & = & \text { Net radiation }\left(\mathrm{W} \mathrm{m}^{-2}\right) \\
\rho & = & \text { Density of air }\left(\mathrm{kg} \mathrm{m}^{-3}\right) \\
\mathrm{c}_{\mathrm{p}} & = & \text { Specific heat of air }\left(\mathrm{J} \mathrm{kg}^{-1} \mathrm{~K}^{-1}\right) \\
\mathrm{r}_{\mathrm{s}} & = & \text { Net resistance to diffusion through the } \\
& & \text { surfaces of the leaves and soil }\left(\mathrm{sec} \mathrm{m}^{-1}\right) \\
\mathrm{r}_{\mathrm{a}} & = & \text { Net resistance to diffusion through the air } \\
& \text { from surfaces to height of measuring } \\
& \text { instruments }\left(\mathrm{sec} \mathrm{m}^{-1}\right) \\
\gamma & = & \text { Hygrometric constant }\left(\gamma \approx 66 \mathrm{~Pa} \mathrm{~K}^{-1}\right) \\
\Delta\left(\mathrm{Pa} \mathrm{K}^{-1}\right)= & \mathrm{e}_{\mathrm{a}} \text { saturated vapor pressure at air } \\
& \text { temperature }\left(\mathrm{m} \mathrm{sec}^{-1}\right) \\
= & \text { Mean vapor pressure }(\mathrm{Pa})
\end{array}
$$

FAO Penman-Monteith equation ${ }^{[1]}$ : FAO P\&M equation is given as follow:

$$
\mathrm{E}_{\mathrm{T}}=\frac{0.408 \Delta\left(\mathrm{R}_{\mathrm{n}}-\mathrm{G}\right)+\gamma \frac{900}{\mathrm{~T}+273} \mathrm{u}_{2}\left(\mathrm{e}_{\mathrm{s}}-\mathrm{e}_{\mathrm{a}}\right)}{\Delta+\gamma\left(1+0.34_{\mathrm{u}_{2}}\right)}
$$


Where:

$\mathrm{R}_{\mathrm{n}}=$ The net radiation at the crop surface $\left(\mathrm{MJm}^{-2}\right.$ day $\left.^{-1}\right)$

$\mathrm{G}=$ The soil heat flux density $\left(\mathrm{MJm}^{-2} \mathrm{day}^{-1}\right)$

$\mathrm{T}_{\text {mean }}=$ The mean daily air temperature at $2 \mathrm{~m}$ height $\left({ }^{\circ} \mathrm{C}\right)$

$\mathrm{u}_{2}=$ The wind speed at $2 \mathrm{~m}$ height $\left(\mathrm{m} \mathrm{sec}^{-1}\right)$

$\mathrm{e}_{\mathrm{s}} \quad=$ The saturation vapor pressure $(\mathrm{kPa})$

$\mathrm{e}_{\mathrm{a}}=$ The actual vapor pressure $(\mathrm{kPa})$

$\mathrm{e}_{\mathrm{s}}-\mathrm{e}_{\mathrm{a}}=$ The saturation vapor pressure deficit $(\mathrm{kPa})$

$\Delta=$ The slope of the vapor pressure curve $(\mathrm{kPa}$ ${ }^{\circ} \mathrm{C}^{-1}$ )

$\mathrm{G}=$ The psychrometrics constant $\left(\mathrm{kPa}^{\circ} \mathrm{C}^{-1}\right)$

The terms in the numerator on the right-hand side of the equation are available energy force and air dryness indicator, respectively for daily computation, at maximum and minimum air temperatures at $1.5-2.5 \mathrm{~m}$ height above surface $(\mathrm{kPa})^{[15]}$.

Hargreaves equation ${ }^{[11]}$ : This equation is expressed as:

$$
\mathrm{E}_{\mathrm{T}}=0.0023\left(\mathrm{~T}_{\mathrm{m}}+17.8\right)\left(\sqrt{\mathrm{T}_{\max }-\mathrm{T}_{\min }}\right) \mathrm{R}_{\mathrm{a}}
$$

Where:

$\mathrm{T}_{\mathrm{m}}=$ Daily mean air temperature $\left({ }^{\circ} \mathrm{C}\right)$

$\mathrm{T}_{\max }=$ Daily maximum air temperature $\left({ }^{\circ} \mathrm{C}\right)$

$\mathrm{T}_{\text {min }}=$ Daily minimum air temperature $\left({ }^{\circ} \mathrm{C}\right)$

$\mathrm{R}_{\mathrm{a}} \quad=$ Extraterrestrial radiation

The mean air temperature in the Hargreaves equation is calculated as an average of $T_{\max }$ and $T_{\min }$ and $R_{a}$ is computed from information on location of the site and time of the year.

Statistical analysis: One-way Anova was performed to analyze the differences between three methods. The Statistical Analysis System (SAS) version 9.1 was used in this work. Statistics analysis included the maximum, minimum, mean and standard deviation of ET calculations. Besides these data, the Coefficient Variation, Root Mean Square Error (RMSE), R-square was determined.

\section{RESULTS AND DISCUSSION}

Average annual total rainfall in study area is about 2996.3 and the monthly precipitation for period of study is show in Fig. 2. This parameter is mostly changed between 100 and $400 \mathrm{~mm} \mathrm{month}^{-1}$.
Monthly maximum and minimum air temperature and monthly humidity for study site is show in Fig. 3 and 4 respectively. In tropical zone the fluctuation of temperature is almost same throughout the year. Humidity has been changed between 93 and $95 \%$ month $^{-1}$.

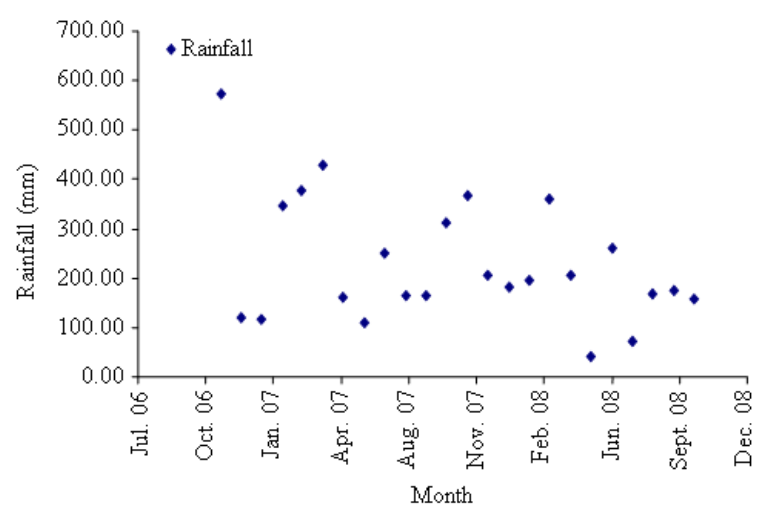

Fig. 2: Average annual total precipitation

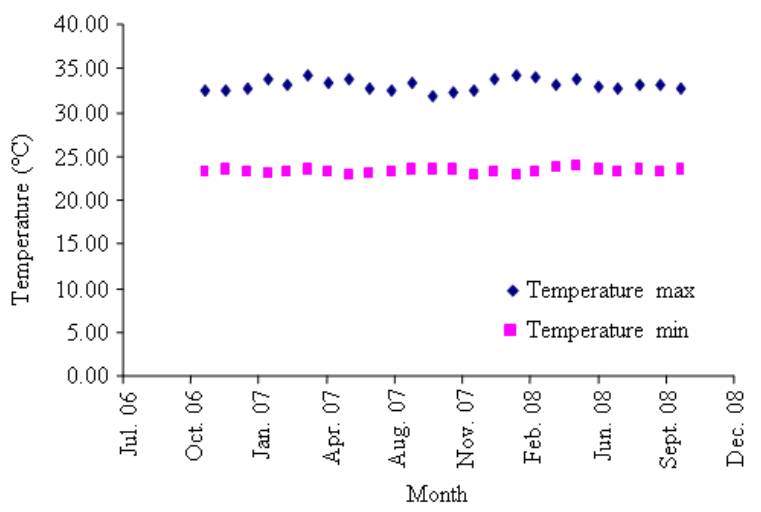

Fig. 3: Monthly maximum and minimum temperature

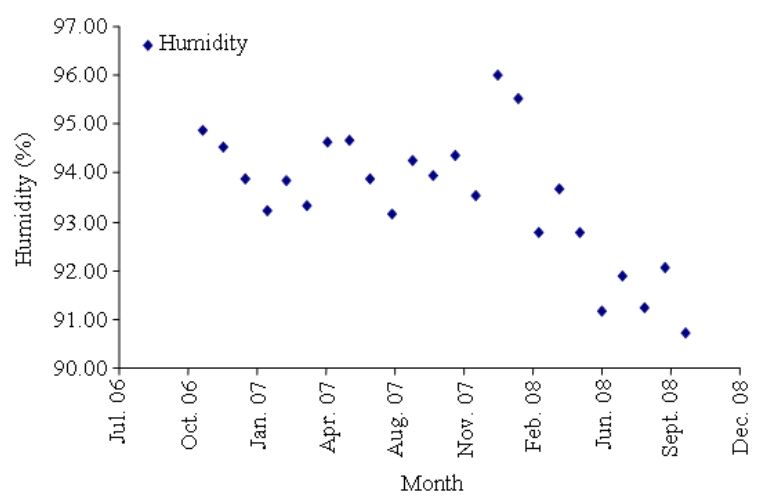

Fig. 4: Humidity of the research area 
Am. J. Environ. Sci., 5 (6): 698-705, 2009

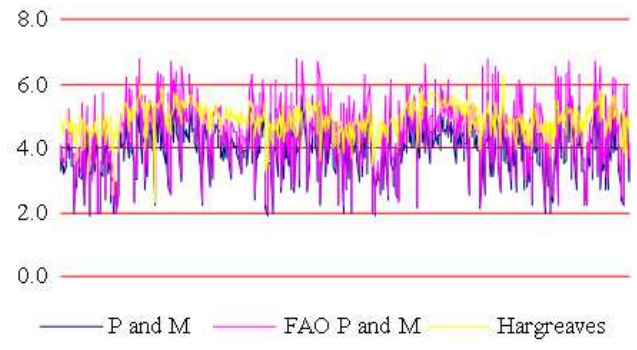

Fig. 5: Estimate daily ET by three methods

\begin{tabular}{llll}
\multicolumn{4}{l}{ Table 1: Max., min., mean daily value of three methods } \\
\hline ET methods & $\begin{array}{l}\text { P\&M } \\
\left(\mathrm{mm} \mathrm{day}{ }^{-1}\right)\end{array}$ & $\begin{array}{l}\text { FAO P\&M } \\
\left(\mathrm{mm} \mathrm{day}^{-1}\right)\end{array}$ & $\begin{array}{l}\text { Hargreaves } \\
\left.(\mathrm{mm} \mathrm{day})^{-1}\right)\end{array}$ \\
\hline Daily ET mean value & 4.89 & 4.42 & 3.91 \\
Daily ET min value & 1.90 & 1.90 & 2.30 \\
Daily ET max value & 5.70 & 6.80 & 6.30 \\
\hline
\end{tabular}

Estimating Daily ET: P\&M, FAO P\&M and Hargreaves methods were used to estimate daily ET for the study period (Nov.1, 2006 until Oct. 31, 2008). The calculation and comparison of daily ET was implemented. Figure 5 illustrates the results of daily ET calculation for the three methods in the study area.

The statistical analysis shows there are significant differences between the three methods. The R-Square is 0.194; Root-MSE is 0.81 Coefficient Var. 18.49. The Average has shown that the results of P\&M and FAO $P \& M$ are near to each other. The mean value of daily ET that was obtained by statistical analysis has proved it. The mean values of P\&M and FOA P\&M are 4.89 and 4.42 respectively while mean value of Hargreaves method for daily calculation was 3.91. Table 1 illustrates the mean, Maximum and minimum daily values of three methods during study period at study area. The results illustrate in Table 1 approved prediction of Hargreaves and Allen ${ }^{[9]}$ about differences between Hargreaves and FAO P\&M equations.

Estimating Monthly ET: P\&M, FAO P\&M and Hargreaves methods were used to estimate monthly ET. The calculation and comparison of monthly ET for Nov. 2006 until Oct. 2008 was implemented. Figure 6 illustrates results of 3 methods.

Statistical analysis on the results has shown that there is a significant difference between all three methods and the R-Square is 0.64, Root-MSE is 9.57, Coefficient Var. 7.17. The results obtained for FAO $\mathrm{P} \& \mathrm{M}$ as modified method of $\mathrm{P} \& \mathrm{M}^{[1]}$ in comparison with benchmark method (P\&M method) has a significant difference. However the mean values of FAO P\&M and P\&M methods are close in comparison with Hargreaves method. Table 2 show mean, minimum, maximum monthly values in study area.

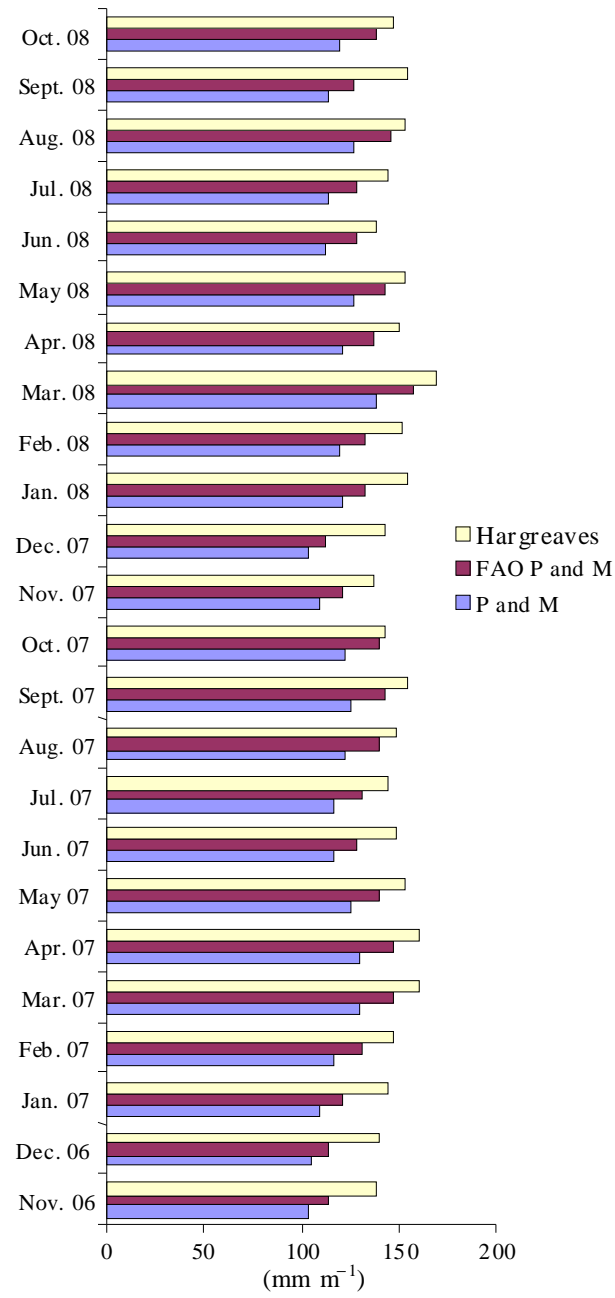

Fig. 6: Estimate monthly ET by three methods

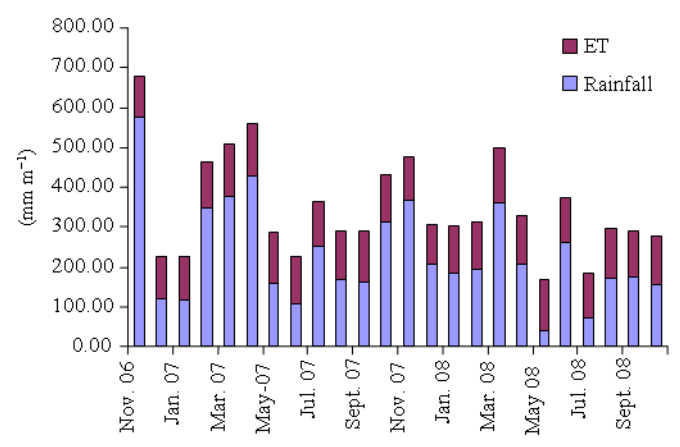

Fig. 7: The two-year annual rainfall and ET

Table 2: Max., min., mean daily value of three methods

\begin{tabular}{llll}
\hline ET methods & $\begin{array}{l}\text { P\&M } \\
\left(\mathrm{mm} \mathrm{m}^{-1}\right)\end{array}$ & $\begin{array}{l}\text { FAO P\&M } \\
\left(\mathrm{mm} \mathrm{m}^{-1}\right)\end{array}$ & $\begin{array}{l}\text { Hargreaves } \\
\left(\mathrm{mm} \mathrm{m}^{-1}\right)\end{array}$ \\
\hline Monthly ET mean value & 118.3 & 132.9 & 149.0 \\
Monthly ET min value & 102.4 & 112.4 & 136.0 \\
Monthly ET max value & 137.7 & 156.8 & 167.9 \\
\hline
\end{tabular}




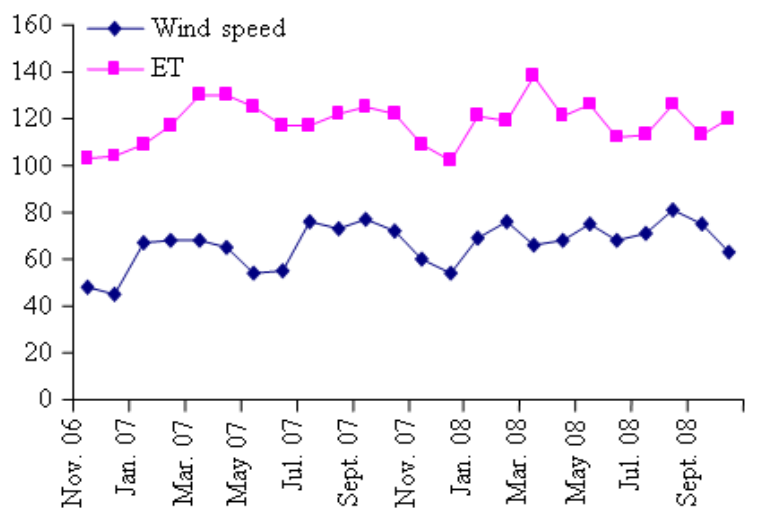

Fig. 8: Comparison ET and wind Speed during study period

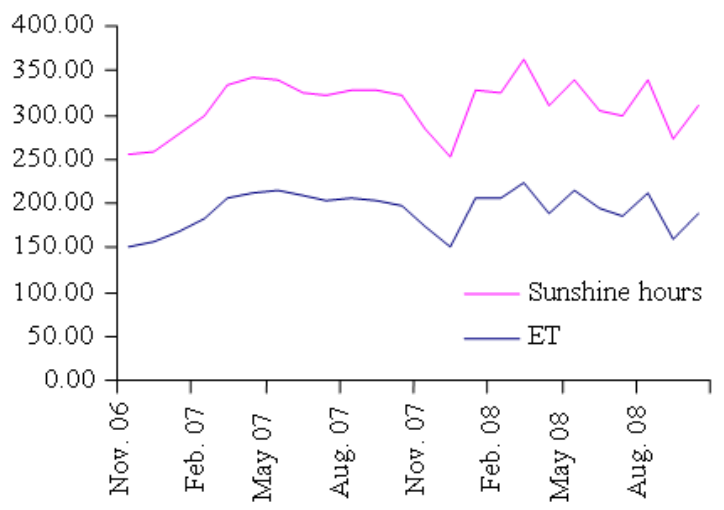

Fig. 9: Comparison ET and wind speed during study period

Generally speaking, the ET is influenced both by meteorological and surface conditions. This mainly includes sunshine hours, air temperature and wind speed $^{[1]}$. In the present study the parameters mentioned above will be assessed and compared with ET (P\&M method) to find the efficiency of main parameters on calculating ET in tropical zone like Malaysia.

Two year annual rainfall and ET results shown that amount of ET in different months with high different amount of rainfall has changed small. Therefore, in tropical and semi-tropical region, even with high amount of rainfall the reason of fluctuation of ET should be assessed in other parameters such as wind speed and sunshine hours. Figure 7 illustrates proportion of rainfall and ET in study area during Nov. 2006 till Oct. 2008. In all of comparisons that are shown here, ET values are according to P\&M equation, which was calculated monthly.

However, the results of wind speed and ET are not exactly the same but Fig. 8 shows in most places are too similar and decreasing and increasing of wind speed has direct proportion on decreasing and increasing of ET.

Fluctuation in sunshine hours coincide with ET changes during the study period. It is obvious that sunshine hours have a significant effect on values of ET. Figure 9 shows variations in both of them are same.

It should be noted that ET has a great influence on the water budget both globally and locally. In the absent of ET, water can be added from surface water to groundwater and stream flow and it would has important effect in water management. In groundwater flow modeling and groundwater contamination modeling, parameter like ET should be assigned accurately to have reliable results. The precise value of ET is important in hydrologic, water-management modeling for reliable results ${ }^{[2]}$. Scientifics mentioned that ET is used typically in groundwater modeling to assess the change in ET flux due to the change in groundwater table.

\section{CONCLUSION}

This study is estimated ET at field study based on three methods which are in agreement by most scientists. The results of statistical comparison have shown that significant difference existed between the three evaluation methods in study area (Coefficient Variant for daily and monthly analysis was 18.49 and 7.17 respectively), however, according to the introduction, some researchers insist that the results of these methods in their study area were the same or near to. It is obvious that mean of P\&M and FAO-P\&M are closed, but not the same yet in present study area. If the Hargreaves method is used for the study region in the absence of sunshine hours, humidity and wind-speed data, the result need some correction to obtain reliable data as accurate as P\&M. However, there are significant differences between results; nevertheless predictions of Hargreaves and Allen ${ }^{[9,10]}$ are right for present research that difference between Hargreaves and FAO-P\&M methods are similar or maximum $1 \mathrm{~mm} / \mathrm{d}$ in tropical locations. The results also have shown sunshine hours and wind speed have important effect on values of ET.

Application of present methods identified that maximum value of evapotranspiration is belong to Hargreaves method and the minimum is belong to $\mathrm{P} \& \mathrm{M}$ and amount of evapotranspiration can be bracketing between them in present area or other sites.

Precise evaluation of ET can be important due to using ET as a raw data in other study such as groundwater modeling. Therefore it is strongly recommended that planning a detailed study to 
determine the precise cause of these differences between these three methods.

\section{REFERENCES}

1. Allen, R.G., L.S. Pereira, D. Raes and M. Smith, 1998. Crop Evapotranspiration: Guidelines for Computing Crop Water Requirements. FAO Irrigat. Drainage Rome, ISBN: 9251038759.

2. Amatya, D.M., R.W. Skaggs and J.D. Gregory, 1996. Camparison of methods for estimating REFET. J. Irrigat. Drainage Eng., 121: 9. DOI: 10.1061/(ASCE)0733-9437(1995)121:6(427).

3. Anadranistakis, M., A. Liakatas, S. Alexandris, S. Aggelides and A. Poulovassilis et al., 1997. Soil heat flux in the penman-monteith evapotranspiration equation. Proceeding of the 2 nd International Symposium on Irrigation of Horticultural Crops, ISHS: Acta Horticulturae, Chania, Crete, Greece, ISBN: 978-90-66058-69-9.

4. Bois, B., P. Pieri, C. van Leeuwen, L. Wald, F. Huard, J.P. Gaudillere and E. Saur, 2008. Using remotely sensed solar radiation data for reference evapotranspiration estimation at a daily time step. Agric. For. Meteorol., 148: 619-630. DOI: 10.1016/j.agrformet.2007.11.005.

5. Droogers, P. and R.G. Allen, 2002. Estimating reference evapotranspiration under inaccurate data conditions. Irrigat. Drainage Syst., 16: 33-45. DOI: 10.1023/A:1015508322413

6. France, J. and J. Thornley, 1984. Mathematical Models in Agriculture. Butterworths, London, ISBN: 10: 085199010X.

7. Gavilán, P., I.J. Lorite, S. Tornero and J. Berengena, 2006. Regional calibration of Hargreaves equation for estimating reference ET in a semiarid environment. Agric. Water Manage., 81: 257-281. DOI: 10.1016/j.agwat.2005.05.001

8. Gavilán, P., J. Estévez and J. Berengena, 2008. Comparison of standardized reference evapotranspiration equations in Southern Spain. J. Irrigat. Drainage Eng., 134: 1-12. http://dx.doi.org/10.1061/(ASCE)07339437(2008)134:1(1)

9. Hargreaves, G.H. and R.G. Allen, 2003. History and evaluation of hargreaves evapotranspiration equation. J. Irrigat. Drainage Eng., 129: 53-63. DOI: 10.1061/(ASCE)0733-9437(2003)129:1(53)

10. Hargreaves, G.H. and R.G. Allen, 2004. Closure to history and evaluation of hargreaves evapotranspiration equation by George $\mathrm{H}$. Hargreaves and Richard G. Allen. J. Irrigate. Drainage Eng., pp: 448. DOI: 10.1061/(ASCE)0733-9437(2004)130:5(448)
11. Hargreaves, G.L., G.H. Hargreaves and J.P. Riley, 1985. Agricultural benefits for Senegal River Basin. J. Irrigat. Drainage Eng., 111: 111-124. DOI: $\quad 10.1061 /(A S C E) 0733-$ 9437(1985)111:2(113).

12. Itenfisu, D., R.L. Elliott, R.G. Allen and I.A. Walter, 2003. Comparison of reference evapotranspiration calculations as part of the ASCE standardization effort. J. Irrigat. Drainage Eng., 129: 440-448. DOI: 10.1061/(ASCE)0733-9437(2003)129:6(440)

13. Jensen, M.E., R.D. Burman and R.G. Allen, 1990. Evapotranspiration and irrigation water requirements (ASCE Manuals and Reports on Engineering Practice No. 70) ASCE: ISBN: 0872627632. pp: 360.

14. Kang, S., S.R. Evett, C.A. Robinson and W.A. Payne, 2009. Simulation of winter wheat evapotranspiration in Texas and Henan using three models of differing complexity. Agric. Water Manage., 96: 167-178. DOI: 10.1016/j.agwat. 2008. 07.006.

15. Kim, C.P. and D. Entekhabi, 1997. Examination of two methods for estimating regional evaporation using a coupled mixed layer and land surface model. Water Resour. Res., 33: 2109-2116. http://www.agu.org/pubs/crossref/1997/97WR0156 4.shtml

16. Kosugi, Y. and M. Katsuyama, 2007. Evapotranspiration over a Japanese cypress forest. 2. Comparison of the eddy covariance and water budget methods. J. Hydrol., 334: 305-311. DOI: 10.1016/j.jhydrol.2006.05.025

17. Landeras, G., A. Ortiz-Barredo and J.J. Lo pez, 2008. Comparison of artificial neural network models and empirical and semi-empirical equations for daily reference evapotranspiration estimation in the basque country Northern Spain. Agric. Water Manage., 95: 553-565. DOI: 10.1016/j.agwat.2007.12.011

18. Linsley, R.K., M.A. Kohler, J.L.H. Paulhus and J.S. Wallace, 1958. Hydrology for Engineers. McGraw Hill, New York, ISBN: 13: 9780070379565.

19. McNaughton, K.G. and P.G. Jarvis, 1984. Using the penman-monteith equation predictively. Agric. Water Manage., 8: 263-278. DOI: 10.1016/03783774(84)90057-X.

20. Monteith, J.L. and M.H. Unsworth, 1990. Principles of environmental physics. 2nd Edn., United Kingdom, London, ISBN: 13: 978-0-71312931-1. 
21. Monteith, J.L., 1965. Evaporation and the environment. Proceeding of the 19th International Symposium on Society Experimental Biology, (ISSEB'65), Swansea Cambridge University, Cambridge, England, pp: 205-234. PMID: 532156

22. Monteith, J.L., 1973. Principles of environmental physics, United Kingdom, London, ISBN: 10: 07131-2931-X

23. Nandagiri, L. and G.M. Kovoor, 2005. Sensitivity of the food and agriculture organization penmanmonteith evapotranspiration estimates to alternative procedures for estimation of parameters. J. Irrigat. Drainage Eng., 131: 238-248. http://dx.doi.org/10.1061/(ASCE)07339437(2005)131:3(238)

24. Suleiman, A.A. and G. Hoogenboom, 2007. Comparison of priestley-taylor and FAO-56 penman-monteith for daily reference evapotranspiration estimation in Georgia. J. Irrigat. Drainage Eng., 133: 175-182. DOI: 10.1061/(ASCE)0733-9437(2007)133:2(175)

25. Sumner, D.M. and J.M. Jacobs, 2005. Utility of penman-monteith, priestley-taylor, reference evapotranspiration and pan evaporation methods to estimate pasture evapotranspiration. J. Hydrol., 308: 81-104. DOI: 10.1016/j.jhydrol.2004.10.023

26. Sun, L. and C. Song, 2008. Evapotranspiration from a freshwater marsh in the Sanjiang plain, Northeast China. J. Hydrol., 352: 202-210. DOI: 10.1016/j.jhydrol.2008.01.010.
27. Temesgen, B., S. Eching, B. Davidoff and K. Frame, 2005. Comparison of some reference evapotranspiration equations for California. J. Irrigat. Drainage Eng., 131: 73-84. DOI: 10.1061/(ASCE)0733-9437(2005)131:1(73)

28. Trajkovic, S., 2005. Temperature-based approaches for estimating reference evapotranspiration. $\mathrm{J}$. Irrigat. Drainage Eng., 131: 316-323. DOI: 10.1061/(ASCE)0733-9437(2005)131:4(316)

29. Zhang, B., S. Kang, F. Li and L. Zhang, 2008. Comparison of three evapotranspiration models to Bowen ratio-energy balance method for a vineyard in an arid desert region of northwest China. Agric. For. Meteorol., 148: 1629-1640. DOI: 10.1016/j.agrformet.2008.05.016. 